\title{
Evaluating Food Waste Handling Using Trios Monitoring System on Soy Industry in Bali, Indonesia
}

\author{
I Ketut Irianto", Gede Yohanes Arygunartha ${ }^{\#}$ \\ \#Agrotechnology Faculty, Warmadewa University, Denpasar, Bali, 80239, Indonesia \\ E-mail: irianto65spl@gmail.com, Anez.ary25@gmail.com
}

\begin{abstract}
The purpose of this paper is to analyze a series of operational systems for biofilter technology. The object of research is an area of Wastewater Treatment in the food industry Denpasar, Bali. The Trios System Monitoring Method can be analyzed in three stages of the process of pre-treatment, treatment, stabilization, and three treatments. Biology analyzes settings (giving oxygen, feeding the number of food microorganisms F/M/ ratio, speed of waste flow). The analysis shows that biofilter technology is a technology that uses physical and biological treatment without using chemicals. Physical treatment is carried out by filtration, flotation, sedimentation. Biological treatment is carried out by regulating oxygen delivery with aeration period of 24 hours/day, microorganism feeding $\mathrm{F} / \mathrm{Mg} / \mathrm{BOD} / \mathrm{MLSS} /$ day ratio $0.05-0.2$ with $100 \%$ proven waste flow BOD decreases by $80 \%$ pre-stage treatment. The wastewater is forwarded to the biofilter pond and given physical treatment, biological, and tricking filter in speed regulation, treatment process stage, liquid waste originating from conventional ponds is inserted into the aeration pond with aeration period of 6.0-9.0/hour. Feeding microorganisms F/Mg/BOD/day/MLSS ratio 0.2-0.5 with the waste flow 50\%, BOD decreased by $85 \%$. Feeding microorganisms F/Mg/BOD/day/MLSS ratio 0.2 - 0.5 oxygen administration with aeration period of 6.0-9.0/hour, BOD decreased by $85-90 \%$.
\end{abstract}

Keywords - food waste handling; trios monitoring system; soy sauce industry.

\section{INTRODUCTION}

So far, the quality and characteristics are used as indicators of the success of waste management, even though the quality of the handling results is also determined by the stages of the process and the treatment given. The quality and characteristics of each industry's waste are different. Waste is influenced by human activities, the amount of waste, raw materials of waste, sources of raw materials of waste and processing stages and the treatment given at each step of the process [1]. Most of the technology used in some companies are not following the goals and principles of waste treatment. There are three objectives of waste treatment, namely: to remove pollutants, reduce pollutants, and reuse waste (recycle). The trios monitoring system method is a method that monitors three stages of the process and treatment and can recommend technology standards following the treatment objectives. The technology used is guided by the principles of biology with technology that is safe, efficient, and environmentally friendly. Safe not to use chemicals, efficient (inexpensive) environmentally-friendly (the results of the process do not pollute the environment). The quality of the results of the technology process is determined by the approach with multi variables and the treatment given at each alternative stage of the process [2].
Liquid waste in large quantities and high levels of pollution must go through an integrated process stage through a series of use of technological systems in municipal solid waste and industrial waste [3]. Tool components, contained in technology such as aerators, biological disk drive systems, tricking filters. Other studies such as [4] For biological processes to continue to need operational, technical arrangements such as providing oxygen (aerator), regulating wastewater flow (recirculation of sludge), residual time of waste through the biological disk drive system, tricking filters are filtering tools (filtration) as well as a means to speed up the process of breaking down particle components into smaller sizes and will also affect the quality of waste for that required the right standard in providing treatment.

Some studies found that an oxygen aeration period of 20 hours/day can reduce pollutants by $62 \%$ (BOD, COD) and affect the bioactivity of microorganisms, influent microorganisms waste (1) temperature, and $\mathrm{pH}$ in each pond [5]-[7]. Whereas the regulation of waste flow can accelerate biological processes [5], [8]. Some studies also revealed the provision of aeration flow waste period of 2 hours/day can increase the number of food microorganisms by $\mathrm{F} / \mathrm{M}$ ratio [9]-[11]. Through proper management (operational techniques) will affect all processes and wastewater quality. expected [12]. For this reason, it is necessary to arrange an 
integrated physical, chemical and biological treatment through biological operational techniques. This is following the operational standards of wastewater treatment technology [5]. In addition to tools, microorganisms also play an active role in the process of overhauling pollutants (pollutants) such as groups of bacteria, fungi, protozoa, and algae [13] and digesting heavy metals $\mathrm{Pb}, \mathrm{Cd}, \mathrm{Ni}$, fluent, and mercury ions [14]. Some possible biological processes can occur due to the activities of each group in different environments.

The use of waste treatment technology is subject to remove phenol in water [15]. Biofilter technology is one of the wastewater treatment technologies that use the principle of biology (biological system) that has been applied in food companies (soy sauce industry), where the results of wastewater treatment have been used limited for watering plants. Biofilter technology consists of the stages of the process of pre-treatment, treatment, and stabilization. Each stage of the process is given an integrated physical and biological treatment through the process of decomposition, fermentation, and mineralization. To continue the biological process that involves several types of microorganisms, it is necessary: physical, biological, and chemical treatment [16], [17].

Physical treatment is done by filtration (filtering), sedimentation precipitating), aimed at breaking down waste component components into more straightforward compound sizes. Biological treatment aims to condition the environment such as regulation of temperature, $\mathrm{pH}$, oxygen regulation, regulation of the flow (recirculation) regulation of food/microorganisms $(\mathrm{F} / \mathrm{M})$ ratio of the regulation of waste time (detention time) aims to accelerate bioactivity in spurring the growth of microorganisms in deciphering (biodegradation) pollutant [18], [19]. This arrangement will affect the quality and characteristics and objectives of waste management. Chemical treatments tested by administering chemicals can extract molecules and remove pollutants, especially pollutants that cannot be deciphered biologically (biology system) and have an impact on the environment [20]. All these treatments can be arranged in an integrated manner in a series of technological systems.

Some genera of bacteria that are known to participate in the process of treating biological wastewater include Flavobacterium, Alcaligenus, Pseudomonas, Zooglea, Enterobacter, Escherichia, Citrobacter, Klebsiella, Bacillus, Nitrobacter, Nitrosomonas, Rhodopseudomonas, Cellulomonas, Chromatic, Sphaerotillus and Lothothrix [12] Lept.

Based on the above process, there will be a process of decomposition, fermentation, and mineralization, which involves the type and number of microorganisms. in addition to changing the content of inorganic elements into organic, it also changes elements into mineral salts formation of the process of degradation of pollutant particle components [21]. As a result of biological processes, in addition to being able to remove pollutants, it also simplifies the size of particle components and converts the elements so that they become simpler shapes and can be recycled according to the desired quality standard. Furthermore, it is said that technology that is safe, efficient and environmentally friendly is a technology based on biological system (biological system), that is, it does not use chemicals, only regulates the flow of waste (recirculation sludge), residence time of waste) and the supply of oxygen, food microorganisms (F/M ratio) according to by its standards and designation. The characteristics of industrial waste consist of $31 \%$ BOD, $24 \%$ phosphate, $50 \%$ phenol, $42 \%$ chlorine, others $17 \%$. shows that oxygen is administered for 13 hours/day and, $100 \%$ waste flow can reduce the BOD level by $58 \%$ from the BOD load $173 \mathrm{~g} / \mathrm{m} 3 /$ day [22]. According to oxygen supply accelerates the bioactivity of microorganisms, so that microorganisms found in each stage of the process can degrade the pollutant particles (decomposition process can reduce the waste component particles. The fermentation process can convert inorganic materials into organic matter.

All these processes involve types of microorganisms in certain environmental conditions) environmental conditions in question are temperature $\mathrm{pH}$, type of microorganisms, the amount of organic material. All processes are managed through a series of technological systems. The feasibility of handling liquid waste using biofilter technology to be utilized and discharged into the waters needs to be tested using the trios monitoring system method for each process stage and technological treatment, then compared with the standard quality standards for liquid waste Permenkes RI Number 416 / MENKES / PER / IX / 1990, group D water quality standard KLH Decree No -02 / MENKLH / 1/1988.

\section{MATERIALS AND METHODS}

\section{A. Research Design}

All design research was conducted in the four stages. All paragraphs must be justified, i.e. both left-justified and right-justified.

1) Stage 1. Study the handling of liquid waste: Study the handling of liquid waste in food companies (soy sauce industry) that uses biofilter technology. This study was carried out to confirm that biofilter technology has met the standard criteria for safe and efficient biological-based wastewater treatment systems.

2) Stage 2. Study the treatment: Studying the treatment given at each stage of the process of this study to determine the physical treatment (filtration, flotation, and sedimentation) and biology (giving oxygen, feeding microorganisms F/M ratio, regulating the flow of waste, and the residence time of waste given under designation standards (water and agriculture).

3) Stages 3. Study Stages of the biofilter technology process: Biofilter technology process in handling wastewater can be listed in the following figure 1 . In the operational process of biofilter technology, there are three stages in the series of biofilter technology processes, namely Pretreatment (pool A) Treatment (pool B), Stabilization (Pool C) physical treatment is carried out at the treatment stage (Pool B). 


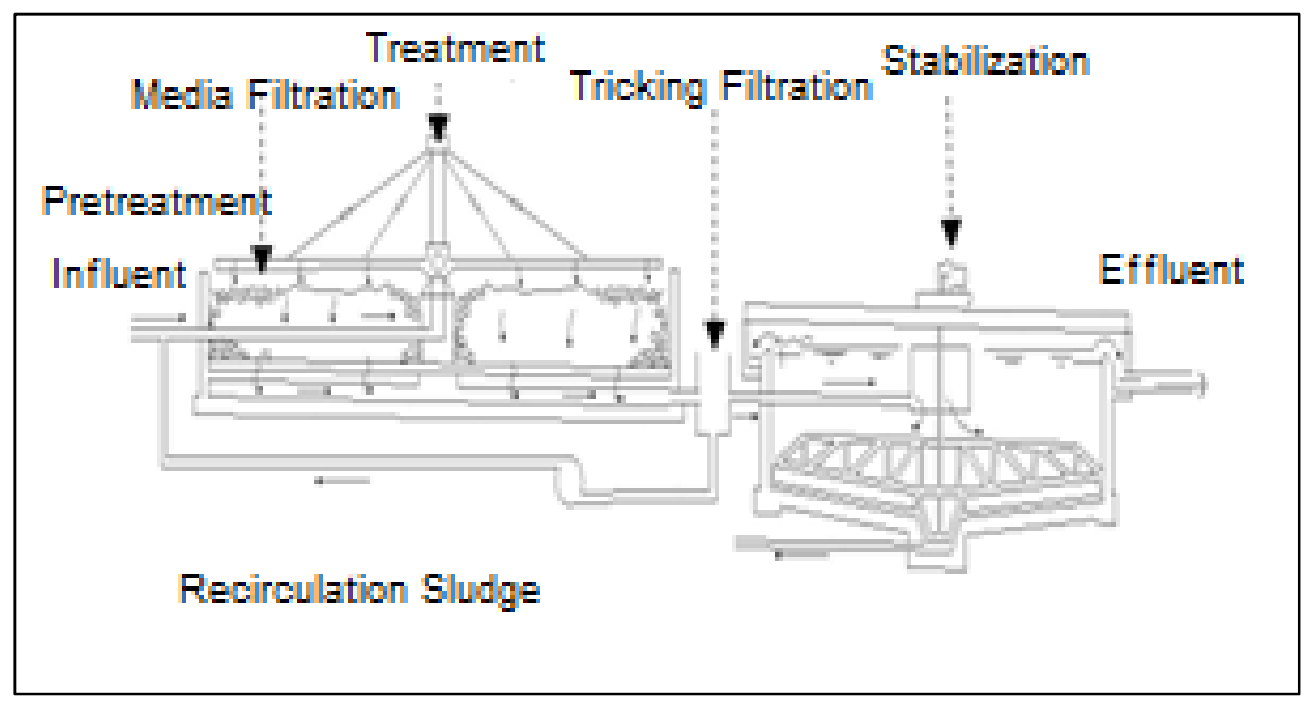

Fig.1 Biofilter Technology Process

- Technology treatment study: In a series of biofilter technology processes, there are two treatments namely Physical treatments such as filtration (filtration), flotation (stirring), sedimentation (deposition). Biological treatments such as oxygen administration, feeding microorganism $\mathrm{F} / \mathrm{M}$ ratio, waste regulation, flow, and waste residence time.

- Study the quality and characteristics of food company wastewater: Three parameters indicate the quality and characteristics of wastewater at each stage of the process, namely: physical, chemical, biological.

4) Stages 4. Physical, chemical, and biological Analysis: Physical parameter analysis of TSS, MLSS using photometric method namely TSS portable handheld Turbidity LXV 322.9900002 product system (GLI International $\mathrm{HACH}$ radiometric analytic) Analysis of chemical parameters such as sulfate, magnesium, ammonia, ammonium acid, COD, BOD, using titrimetric analysis using electrometric analysis and digital titrator, $0.080 \mathrm{M}$ cartridge, Test kit, $500 \mathrm{ml}$ calcium magnesium indicator solution, $50 \mathrm{ml}$ ammonia electrode filling solution, $5 \mathrm{~g} / 100$ $\mathrm{ml}$ phenolphalene indicator solution, TNT plus, BOD incubator. Ammonia and nitrogen parameter analysis using Kjeldah $l$. Nitrogen analysis, Nessler Range: 1-150 mg/l. Nitrates and nitrites used spectrophotometric analysis with the method of 8171 Powder Pillow of Accu Vac range: 0.110.0 mg / 1. NO2-N (HACH ACC Brand). P, K, Ca, Al, Fe, and Mo uses the Atomic absorption spectrophotometer analysis (AA 30, Variant, USA). All metals except calcium use the acetylene and water analysis. Calcium uses the analysis of nitrous oxide and water. Mn using the oxidation period analysis method, range: $0.006-0,700 \mathrm{mg} / 1$ manganese reagent. Biological analysis such as microorganisms and bacteria using the calculation method of 8091 MPN (Most Probable Number) Coliform-total and E Coli Lauryl Tripose w MUG Broth Most Probable. Range: MPN Count table, Dry bath 12-well, $120 \mathrm{~V}$ (HACH, USA Brand) incubator.

\section{B. Research Location and Time}

The study was conducted in the area of the wastewater treatment plant (WWTP) of the food industry in Denpasar,
Bali. The research was conducted in two stages, namely: field research (sampling), laboratory research (sample testing). Field research was carried out starting on October 5, 2016, continuing December 28, 2016, laboratory testing starting on May 20, 2017, and continuing July 20, 2017.

\section{Material and Tools}

Samples were taken from three stages of the operational process of biofilter technology pre-treatment (Pool A), treatment (Pool B) and stabilization (pool C). Characteristics were taken from the stabilization pond. Liquid waste sample testing is carried out in several certified laboratories such as Sanglah Hospital Laboratory, Bali Police Forensic Laboratory Denpasar Bali Indonesia.

\section{RESULTS AND DISCUSSION}

The amount of liquid waste from food companies (soy sauce industry) managed as much as $1100 \mathrm{~m} 3$ /day. An estimated 530 people use water and 50,000 liters/day of clean water for production, of which $86 \%$ then becomes waste. With a WWTP capacity of $129 \mathrm{~m} 3$ / hour (Tables 1 and 2). The results of the laboratory tests for liquid waste of food companies (soy sauce industry) show that the liquid waste of food companies (soy sauce industry) includes domestic waste dominated by organic matter in the form of solids containing organic material in the form of $65 \%$ carbohydrates, $25 \%$ protein, fat and some particles organic leftovers.

\section{A. Component Analysis of Food (Soy) Industry Waste}

The result of the waste component analysis show composting unsure waste material can be described in the following.

1) Solid material waste: Solid waste material in question is a material in the form of solid, both coarse (large granules) and small granules. If the solid waste material dissolves in water, then the density of water or specific gravity of the liquid will be bad and accompanied by changes in color [23]. Some solid waste material which is partially soluble and partially insoluble will form colloids that float in water [24]. 
2) Organic waste: Some solid waste material which is partially soluble and partially insoluble will form colloids that float in water [24]. Organic wastes are generally in the form of waste that can rot or be degraded by microorganisms [25] Waste material could increase the population of microorganisms in the water making it possible to participate in the development of pathogenic bacteria [26].

3) Inorganic waste material: Inorganic waste material is generally in the form of waste that cannot rot and is difficult to be degraded by microorganisms. Inorganic waste material usually comes from industries that involve the use of metal elements such as Lead $(\mathrm{Pb})$ Arsenic (As), Cadmium (Cd), Mercury (Hg), Chrome (Cr), Nickel (Ni), Calcium (Ca), Magnesium (Mg), Cobalt (Co) [27]). The content of Calcium $(\mathrm{Ca})$ and Magnesium $(\mathrm{Mg})$ ions in water causes water to be hard and will inhibit the degradation process [15]. High water hardness can be detrimental because it can damage equipment made of iron. [28].

4) Processed waste material: Environmental water containing processed foodstuffs will contain many microorganisms, including pathogenic bacteria [29]. Processed food ingredients contain amino group proteins which, when degraded by microorganisms, breakdown into volatile and foul-smelling compounds [30].

5) Oily Liquid Disposal Ingredients: Oil cannot dissolve in water but will float on the surface of the water. Oily liquid waste material discharged into environmental water will float covering the surface of the water [31], [32]. There are two types of surface area shrinkage, depending on the type of oil and time [33]. A layer of oil on the surface will prevent oxygen diffusion, block the sun's rays so that the oxygen content in the water decreases.

6) Chemical waste material: chemical waste material varies in variety, but what is meant is water pollutants in the form of soap (detergent, shampoo and other cleaning agents), chemical dyes, and pest eradication agents (insecticides). Excess chemicals in the form of soap (detergent, shampoo and other cleaning agents) that are excessive in water are characterized by the emergence of soap scum on the surface of the water. Soap derived from oil acid (stearic, palmitic, or medicine) which is reacted with bases $N a(\mathrm{OH})$ or $K(\mathrm{OH})$. Detergent can also be a cleaning agent such as soap, but it is made from petrochemical compounds. The detergent commonly used is Dodecyl Benzen Sulfonate. Waste material in the form of soap and detergent in environmental water can increase the $\mathrm{pH}$ of the water environment [16], [20].

TABLE I

OVERVIEW OF THE SOY SAUCE INDUSTRY

\begin{tabular}{|l|l|c|c|}
\hline No & Description & Metric & Unit \\
\hline 1 & Land & 13.3 & Ha \\
\hline 2 & Building area & 68.7632 & $\mathrm{~m} 2$ \\
\hline 3 & Sum of kitchen+ bathroom & 6 & TT \\
\hline 4 & $\begin{array}{l}\text { Production } \\
\text { Room }\end{array}$ & 52 & Rom \\
\hline 5 & Sum of visitor & 742 & Person \\
\hline 6 & Sum of employee & 530 & Person \\
\hline 7 & Water consumption /day & 5,000 & $\mathrm{~m} 3 /$ day \\
\hline 8 & Using electric power & 3,521 & $\mathrm{KWH}$ \\
\hline 9 & Capacity IPAL/J & 129 & $\mathrm{~m} 3 / / \mathrm{hour}$ \\
\hline
\end{tabular}

Source: The research, December 2016
7) Waste Treatment Analysis of Food (Soy) Industry Waste: The results of wastewater treatment as described in Table 2. The measurement results can be seen from the amount of liquid waste, the volume of aeration pool, total influent solids, influent suspended solids, influent BOD, effluent suspended solids, effluent BOD, and MLSS. The measurement results are shown in Table II. The results of the analysis of the treated wastewater component of 1100 $\mathrm{m} 3$ /day obtained the liquid waste component consisting of solid substance $599 \mathrm{mg} / \mathrm{l}$, suspended solids entering the pond (Influent) $100 \mathrm{mg} / \mathrm{l}, \mathrm{BOD}$ entering the pool (Influent) 173 $\mathrm{mg} / 11$ with a capacity of $129 \mathrm{~m} 3$ aeration pond volume is only able to reduce particle components by $38 \%$, it is expected that $70-80 \%$ treatment stage (Table II ).

TABLE II

RESULTS OF MEASUREMENT OF LIQUID WASTE TREATED IN SOY INDUSTRY

\begin{tabular}{|l|l|l|}
\hline Description & Big & Unit \\
\hline $\begin{array}{l}\text { Amount of Liquid } \\
\text { Waste }\end{array}$ & 1100 & $\mathrm{~m} 3 /$ day \\
\hline Pool Volume aeration & 129 & $\mathrm{~m} 3$ \\
\hline Total Solids Influent & 599 & $\mathrm{mg} / \mathrm{l}$ \\
\hline $\begin{array}{l}\text { Suspended solids } \\
\text { Influent }\end{array}$ & 100 & $\mathrm{mg} / \mathrm{l}$ \\
\hline BOD Influent & 173 & $\mathrm{mg} / \mathrm{l}$ \\
\hline $\begin{array}{l}\text { Suspended solids } \\
\text { Effluent }\end{array}$ & 22 & $\mathrm{mg} / \mathrm{l}$ \\
\hline BOD Effluent & 20 & $\mathrm{mg} / \mathrm{l}$ \\
\hline MLSS & 37,41 & $\mathrm{mg} / \mathrm{l}$ \\
\hline
\end{tabular}

This shows a series of processes that have not run optimally such as physical treatment (filtration, flotation, sedimentation, whereas biological treatment has been meeting operational technology standards with a BOD-1300 load treatment of oxygen supply with aeration period of 2.5-3.5 hours/day, treatment of microorganism feeding $\mathrm{F} / \mathrm{Mg} / \mathrm{BOD} / \mathrm{MLSS} /$ day ratio $0.5-1$, 0 with $100 \%$ waste flow can reduce BOD $80-85 \%$ pollutant at the end of the stabilization process.

Low control is not optimal (sludge recirculation) in addition to the high use of chemicals (disinfectants so that the number of microorganisms is less able to degrade pollutants due mainly to the aeration pond and stabilization pond stage, liquid waste resulting from the process is only safe to be used for agriculture in terms of physical, chemical properties and biology proven through a series of biofilter technology processes also able to produce elemental components of $8.6 \mathrm{~kg} /$ day $5.250 \mathrm{~kg} /$ day of nitrogen and $1.05 \mathrm{~kg} /$ day of phosphorus obtained from the calculation of microorganism food requirement with BOD:N:P =100:5:1

\section{B. Analysis of the Operational Process of Biofilter Technology}

Biofilter technology is a series of processes consisting of three stages of the process (stabilization pretreatment treatment). system-based biology because the treatment is given only physically and biology does not use chemicals. 
1) Pre-treatment analysis: Where liquid waste originating from laundry, kitchen, canteen, and production room activities, accommodated in anaerobic equalizer pool (primary clarifier) is given oxygen treatment with aeration period of 24 hours/day, treatment of feeding microorganisms with active sludge ratio $\mathrm{F} / \mathrm{Mg} / \mathrm{BOD} / \mathrm{MLSS} /$ day $0.05-0.2$ with $100 \%$ mudflow proved to be able to reduce pollutants (BOD) by $80 \%$. Then the liquid waste is forwarded to the biofilter pond. Physical treatment occurs here, such as filtration, sedimentation, and flotation in order to obtain a simpler size of liquid waste particles. separation of particle components, namely simplification and decomposition of components of liquid waste particles into simpler forms through biological filtration (sand media) and tricking filter tools are speed regulation tools.

2) Treatment analysis: At the treatment process stage, liquid waste originating from conventional ponds is inserted into the aeration pond here liquid waste is in contact with air, oxygen supply with aerator aeration period 6.0-9.0 / hour, feeding organisms $\mathrm{F} / \mathrm{Mg} / \mathrm{BOD} /$ day ratio/MLSS $0.2-0.5$ with an active sludge flow of $50 \%$ can reduce BOD pollutants $85 \%$ in which microorganisms will convert organic content into inorganic through the fermentation process while removing pollutants such as hydrogen sulfate (H2 S), methane (CH4), ammonia (NH3), Decreasing the amount of carbon dioxide and various organic compounds that are volatile (evaporate) associated with taste and odor. To accelerate the aeration process, oxygen is given through an aerator. For feeding microorganisms, the distribution of active sludge (recirculation of sludge) also influences environmental conditions such as $\mathrm{pH}$ temperature, the number of microorganisms and organic matter) so that biological processes continue to be carried out by regulating the flow of waste through biological means. For feeding microorganisms, the distribution of active sludge (recirculation of sludge) also influences environmental conditions such as $\mathrm{pH}$ temperature, the number of microorganisms and organic matter) so that biological processes continue to be carried out by regulating the flow of waste through biological means.

3) Stabilization analysis: In the stabilization stage (Final clarifier), liquid waste that has undergone the process of removing pollutants in the form of simpler compounds put into a stagnation pool aims to stabilize the components of the liquid waste elements and provide opportunities for macroflora and macrofauna microorganisms such as algae, fungi, protozoa fungi, and bacteria degrade childhood into the forms available for waters. Feeding microorganisms $\mathrm{F} / \mathrm{Mg} / \mathrm{BOD} /$ day/MLSS ratio $0.2-0.5$ oxygen administration with an aeration period of 6.0-9.0 / hour can reduce the amount of BOD pollutants by $85 \%$.

4) Analysis of the quality and characteristics of liquid waste resulting from technological processes. The quality and characteristics of soy sauce industry wastewater show that it is suitable to be used for watering plants and discharged into water. The value of organic matter content in the form of carbohydrates and protein [33],[35] states that the character is the value of the elemental content that dominates the quality of liquid waste. The parameters of liquid waste taken in stabilization ponds (station C) have met the quality standard according to the purpose of waters and agriculture. Physical, chemical and biological parameters are shown in Table III and Table IV.

TABLE III

The Results of Physical Testing of EFFLUENT Quality

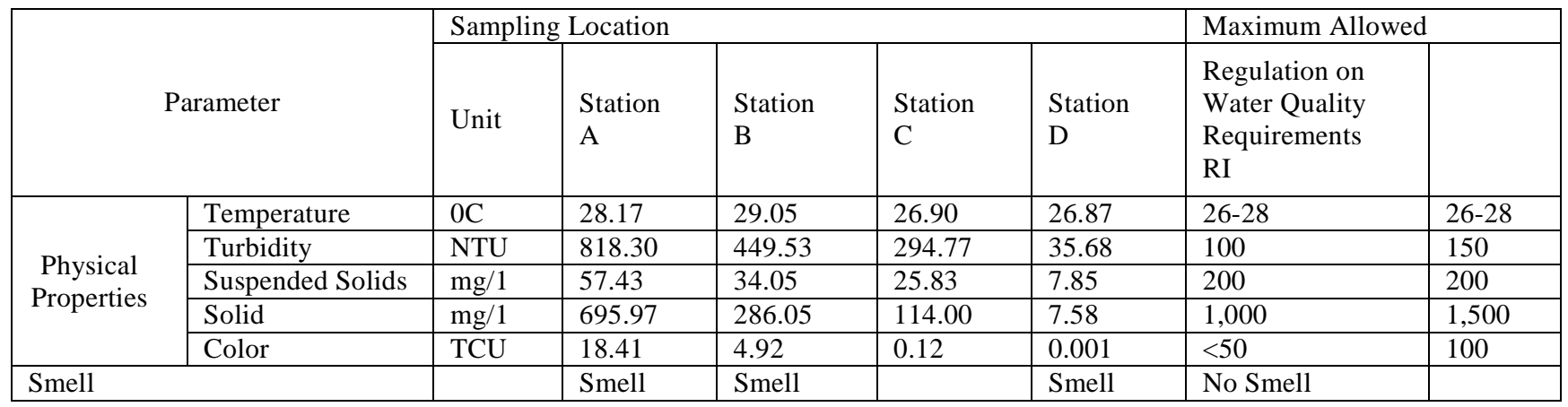

Table III shows the value of physical parameters such as turbidity (decreased $34.42 \%$ ), suspended solids, (decreased $24.14 \%$ ), dissolved solids decreased $(60.14 \%)$, color (decreased 97.56\%), Higher values were obtained at treatment stage A and lowest in the pool stabilization stage C. The highest value of turbidity parameter is $818.30 \mathrm{NTU}$ parameter of suspended solids $57.43 \mathrm{mg} / 1$, dissolved solids $695.97 \mathrm{mg} / \mathrm{l}$ supported by color parameters 18.41 TCU at stage (pretreatment pond A. This shows the high particle component pollutants at that stage (pool A) and the technological system and treatment not yet operating, especially physical treatment. The lowest value was obtained at the treatment stage (pool B) and stabilization (pool C), turbidity parameters $449 \mathrm{mg} / \mathrm{l}$ pool B, 53294 and
77 NTU pond C. Parameters of suspended solids 34.05 $\mathrm{mg} / \mathrm{l}$ pool B, $25.83 \mathrm{mg} / \mathrm{l}$ Pool C, dissolved solids 286,057 $\mathrm{mg} / \mathrm{l}$ pool B $7.58 \mathrm{mg} / \mathrm{l}$ pool C, supported by 4.92 color parameters TCU pool B, 0.12 TCU pool C. This shows technology systems are working, especially biological treatment (oxygen supply, microorganism feeding F/M ratio. Arrangement of waste flow and waste residence time.

Table III shows the value of physical parameters such as turbidity (decreased 34.42\%), suspended solids, (decreased $24.14 \%$ ), Physically, the stages of making soy sauce are included in FLUID regarding Viscosity (viscosity of liquid substances). Viscosity is a measurement of fluid resistance that is changed both by pressure and voltage. In everyday 
matters (and only for fluids), viscosity is "thickness" or "internal friction". Therefore, water that is "thin" has a lower viscosity, while honey that is "thick" has a higher viscosity. Simply put, the lower the viscosity of a fluid, the greater the movement of the fluid.

Viscosity describes the internal resistance of a fluid to flow and may be thought of as a measurement of fluid shift. For example, the high viscosity of magma will create a high and steep stratovolcano, because it cannot flow too far before it cools, whereas the lower viscosity of lava will create a low and wide volcano. All fluids (except superfluid) have resistance to pressure and are therefore called viscous, but fluids without pressure and stress resistance are called ideal fluids.

TABEL IV

The Results of Chemical, Biological Testing of EFFluent Quality

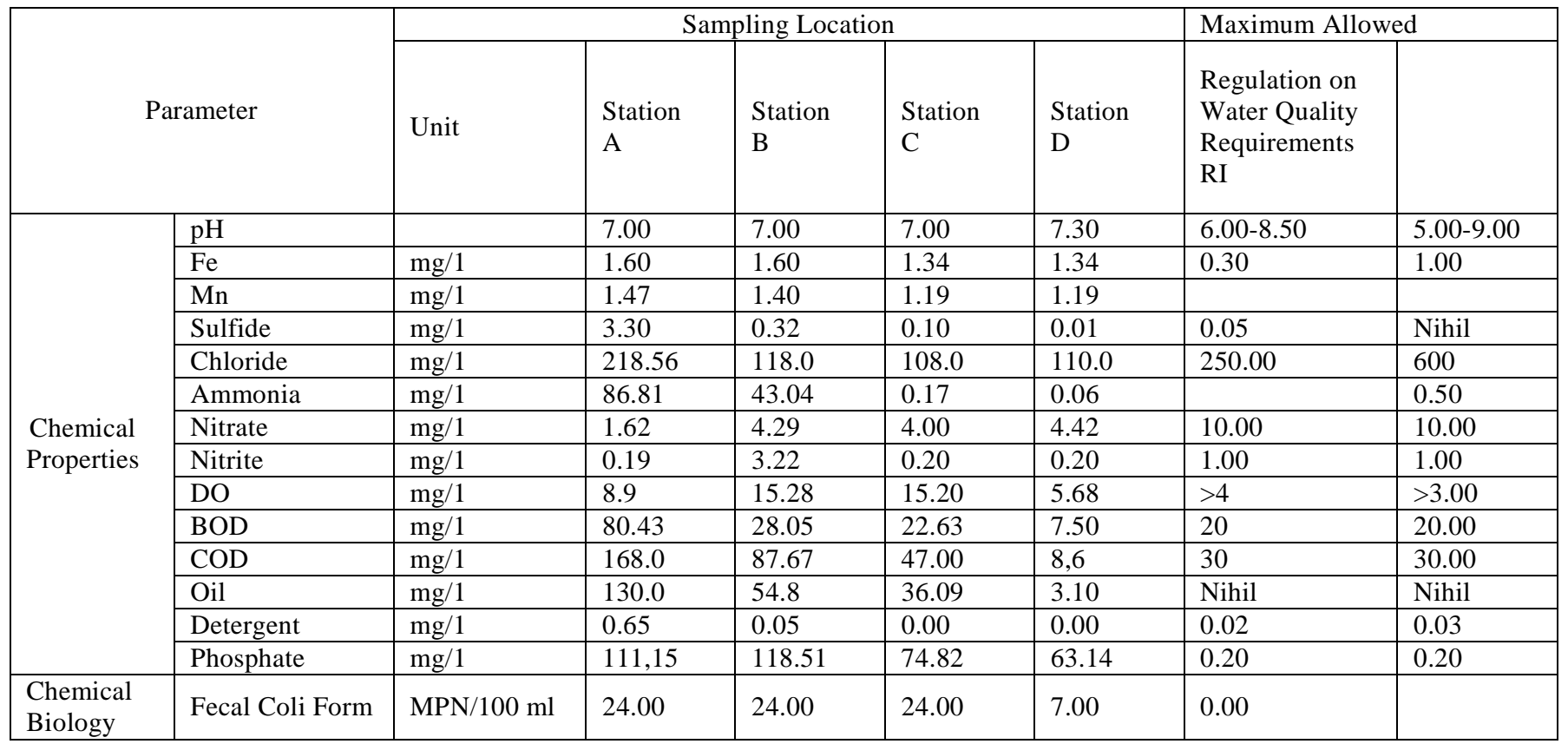

Table IV shows that the results of chemical analysis BOD parameter values (down 19.32\%), COD decreased $46.39 \%$ from the Pretreatment stage of pool A to the stabilization stage of pool $\mathrm{C}$, followed by a decrease in metal elements (Fe decreased by $16.25 \%$, Mn down $15 \%$, sulfide (down 68.75\%), chloride (down 8.48\%), Ammonia (down 99.61\%) and other elements, while DO parameters have increased $(0.7 \%)$ at the pond $\mathrm{A}$ pretreatment stage and pool B treatment (Table IV).

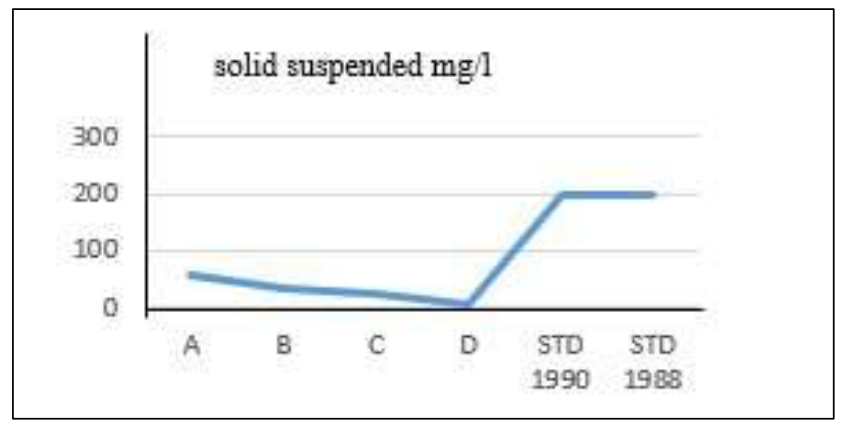

Fig.2. Solid suspended analysis

Fig.2 shows solid suspended differentiation tested and distinguished by two governing standards. Fig. 3 shows the highest value of BOD $80.43 \mathrm{mg} / \mathrm{l}$ COD $168.0 \mathrm{mg} / \mathrm{l}$, Ammonium $86.81 \mathrm{mg} / \mathrm{l}$ was obtained at the pond $\mathrm{A}$ 'pretreatment stage (BOD and the lowest value was obtained at the Pool stabilization stage C Nitrate values, Nitrites experienced fluctuations in values The highest nitrate of $4.29 \mathrm{mg} / \mathrm{l}$ was obtained at the pool B treatment stage and the highest nitrite value of $3.22 \mathrm{mg} / \mathrm{l}$ was obtained at the pre-treatment pond A stage. The lowest nitrite value of $0.20 \mathrm{mg} / \mathrm{l}$ was obtained at the pool stabilization stage $\mathrm{C}$. such as BOD $22.63 \mathrm{mg} / \mathrm{l} \mathrm{Fe}, 1.34$ mg/l Mn 1.19 mg/k, 0.10 mg/l sulfide, Ammonia chloride $0.17 \mathrm{mg} / \mathrm{l})$, and other elements.

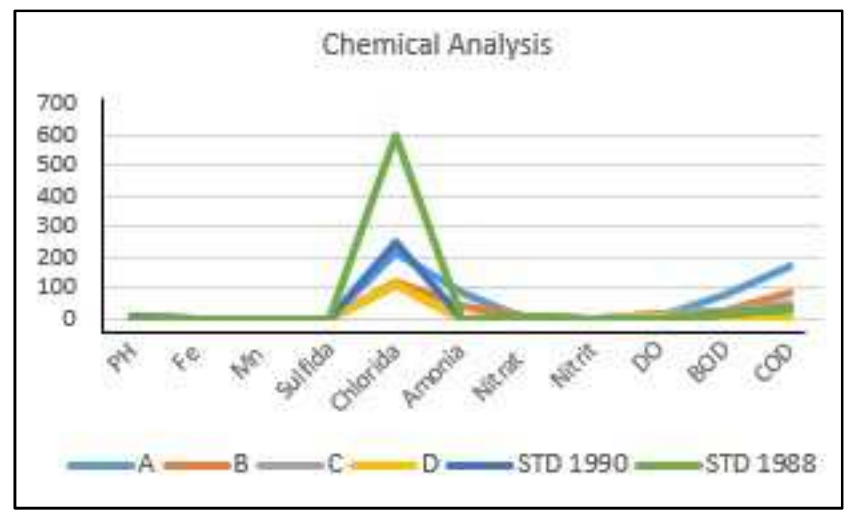

Fig.3 Chemical Analysis

Figure 3 shows that almost all series of processes (pretreatment treatment, microorganism stabilization). Fig.4 is a processed biofilter technology as bacteria. The highest value of $24 \mathrm{MPN} / 100 \mathrm{ml}$, evidenced by noncoliform biofilm mucus simpler size), the fermentation process (converting inorganic material to organic matter, mineralization process (converting organic material into 
mineral salts). All these processes involve microorganisms., supported by environmental conditions such as standard $\mathrm{pH} 6-8.5$, temperature 260C- 280C, the availability of MLSS (mixed liquid suspension solid) microorganisms food amounting to $37.41 \mathrm{mg} / \mathrm{l}$, which is following the standard of living of aquatic microorganisms. MENKLH / 1/2013).

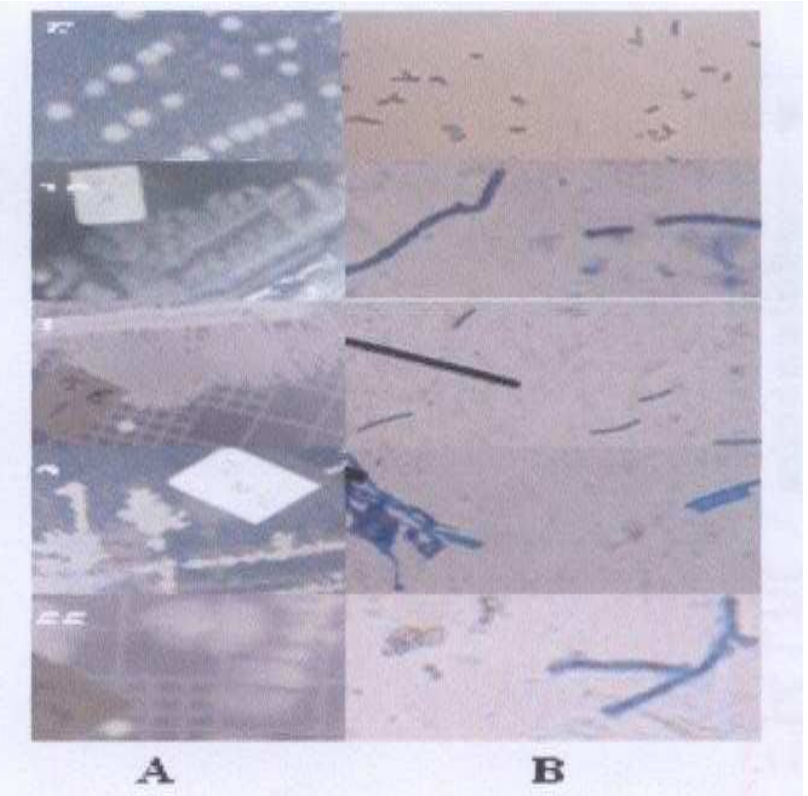

Fig.4. Bacteria that form biofilm mucus Macroscopically (A) and microscopically (B)

\section{CONCLUSION}

The trios monitoring system method shows that soy sauce industry food waste in large quantities is dominated by high organic matter content. The highest values of BOD $80.43 \mathrm{mg} / \mathrm{l}$, COD $168.0 \mathrm{mg} / \mathrm{l}$, Ammonium $86.81 \mathrm{mg} /$ 1 were obtained at the A. biological pond pretreatment stage given. Biofilter technology is a series of processes consisting of three stages of the process (stabilization pretreatment treatment). System-based biology because the treatment is given only physically and biology does not use chemicals.

Liquid waste originating from laundry, kitchen, canteen, and production room activities, accommodated in anaerobic equalizer pool (primary clarifier) given oxygen treatment with aeration period of 24 hours/day, treatment of feeding microorganisms giving active sludge $\mathrm{F}$ ratio/Mg/BOD/MLSS/day $0.05-0.2$ with $100 \%$ mudflow proved to be able to reduce pollutants (BOD) by $80 \%$ (pretreatment stage).

Then the liquid waste is forwarded to the biofilter pond. Physical treatment occurs here, such as filtration, sedimentation, and flotation in order to obtain a more modest size of liquid waste particles. Separation of particle components, namely simplification and decomposition of liquid waste particle components into a more straightforward form through biological filtration (sand media) and tricking filter tools are speed regulation tools (Figure 3).

At the treatment process stage, liquid waste originating from conventional ponds is inserted into the aeration pond here liquid waste is in contact with air, oxygen supply with aerator aeration period 6.0-9.0 / hour, feeding organisms $\mathrm{F} / \mathrm{Mg} / \mathrm{BOD} /$ day ratio/MLSS $0.2-0.5$ with an active sludge flow of $50 \%$ can reduce BOD pollutants $85 \%$ in which microorganisms will convert organic content into inorganic through the fermentation process while removing pollutants such as hydrogen sulfate (H2 S), methane (CH4), ammonia (NH3), Decreasing the amount of carbon dioxide and various organic compounds that are volatile (evaporate) associated with taste and odor.

To accelerate the aeration process, oxygen is given through an aerator. Microorganism feeding is done by activating sludge (sludge recirculation) as well as influencing environmental conditions such as $\mathrm{pH}$ temperature, the number of microorganisms and organic matter) so that biological processes continue to be carried out by regulating the flow of waste through a biological device (Figure 2).

In the stabilization stage (Final clarifier), liquid waste that has undergone the process of removing pollutants in the form of simpler compounds put into a stagnation pool aims to stabilize the components of the liquid waste elements and provide opportunities for macroflora and macro fauna microorganisms such as algae, fungi, protozoa fungi, and bacteria degrade childhood into the forms available for waters. Feeding microorganisms F / $\mathrm{Mg} / \mathrm{BOD} / \mathrm{day} / \mathrm{MLSS}$ ratio 0.2 - 0.5 oxygen administration with aeration period of $6.0-9.0$ / hour can reduce the amount of BOD pollutants by $85 \%$.

Liquid waste resulting from safe technological processes does not contain heavy metal elements, especially in the stabilization pond seen from the measurement of the quality of liquid waste, physically chemical and biological. It can only be used for agricultural activities and household activities Air Quality Standard Gol. D. Ministry of Environment Decree No. Kep-02 / MENKLH / 1/2001. Suggestions given referring to the results of the research are expected that all food companies before disposing and utilizing waste must go through the waste treatment process using biofilter technology because it is safe (not using chemicals, efficient, environmentally friendly.

\section{ACKNOWLEDGMENT}

We would like to thank the technology research ministry Institution which provided a place to publish the results of this scientific work

\section{REFERENCES}

[1] O. Thomas and M. F. Thomas, "Industrial wastewater," in UVVisible Spectrophotometry of Water and Wastewater, 2017.

[2] M. N. Chong, B. Jin, C. W. K. Chow, and C. Saint, "Recent developments in photocatalytic water treatment technology: A review," Water Research. 2010.

[3] F. M. Liew, M. E. Martin, R. C. Tappel, B. D. Heijstra, C. Mihalcea, and M. Köpke, "Gas Fermentation-A flexible platform for commercial scale production of low-carbon-fuels and chemicals from waste and renewable feedstocks," Frontiers in Microbiology. 2016.

[4] C. Aciu, D. A. Ilutiu-Varvara, D. L. Manea, Y. A. Orban, and F. Babota, "Recycling of plastic waste materials in the composition of ecological mortars," in Procedia Manufacturing, 2018.

[5] J. Chen, B. Yao, C. Li, and G. Shi, "An improved Hummers method for eco-friendly synthesis of graphene oxide," Carbon N. Y., 2013 . 
[6] N. Marashlian and M. El-Fadel, "The effect of food waste disposers on municipal waste and wastewater management," Waste Manag. Res., 2005.

[7] W. Sun, C. Xia, M. Xu, J. Guo, and G. Sun, "Application of modified water quality indices as indicators to assess the spatial and temporal trends of water quality in the Dongjiang River," Ecol. Indic., 2016.

[8] S. Fuhrimann et al., "Microbial contamination along the main open wastewater and storm water channel of Hanoi, Vietnam, and potential health risks for urban farmers," Sci. Total Environ., 2016.

[9] M. Zhu, F. Lü, L. P. Hao, P. J. He, and L. M. Shao, "Regulating the hydrolysis of organic wastes by micro-aeration and effluent recirculation," Waste Manag., 2009.

[10] S. Xu, A. Selvam, and J. W. C. Wong, "Optimization of microaeration intensity in acidogenic reactor of a two-phase anaerobic digester treating food waste," Waste Manag., 2014.

[11] P. J. Dube, M. B. Vanotti, A. A. Szogi, and M. C. GarcíaGonzález, "Enhancing recovery of ammonia from swine manure anaerobic digester effluent using gas-permeable membrane technology," Waste Manag., 2016.

[12] Y. Wei, J. Li, D. Shi, G. Liu, Y. Zhao, and T. Shimaoka, "Environmental challenges impeding the composting of biodegradable municipal solid waste: A critical review," Resources, Conservation and Recycling. 2017.

[13] M. Palela, G. Ifrim, and G. Bahrim, "Microbial and Biochemical Characterization of Dairy and Brewery Wastewater Microbiota," Food Technol., 2005.

[14] U. Aiman, A. Mahmood, S. Waheed, and R. N. Malik, "Enrichment, geo-accumulation and risk surveillance of toxic metals for different environmental compartments from Mehmood Booti dumping site, Lahore city, Pakistan," Chemosphere, 2016.

[15] N. Landi et al., "A haem-peroxidase from the seeds of Araujia sericifera: Characterization and use as bio-tool to remove phenol from aqueous solutions," Biocatal. Agric. Biotechnol., 2019.

[16] W. T. Lai et al., "A review: Modified agricultural by-products for the development and fortification of food products and nutraceuticals," Trends in Food Science and Technology. 2017.

[17] J. K. Ludwig, "Green Chemistry: An Introductory Text," Green Chem. Lett. Rev., 2017.

[18] Y. Lu, X. Wu, and J. Guo, "Characteristics of municipal solid waste and sewage sludge co-composting," Waste Manag., 2009.

[19] Q. Xu, Y. Tian, S. Wang, and J. H. Ko, "A comparative study of leachate quality and biogas generation in simulated anaerobic and hybrid bioreactors," Waste Manag., 2015.

[20] S. Ghosh, A. Gillis, J. Sheviryov, K. Levkov, and A. Golberg, "Towards waste meat biorefinery: Extraction of proteins from waste chicken meat with non-thermal pulsed electric fields and mechanical pressing," J. Clean. Prod., 2019.
[21] Ó. J. Sánchez, D. A. Ospina, and S. Montoya, "Compost supplementation with nutrients and microorganisms in composting process," Waste Management. 2017.

[22] Prayitno, K. Zaenal, B. Yanuwiadi, and R. W. Laksmono, "Study of Hospital Wastewater Characteristic in Malang City," Res. Inven. Int. J. Eng. Sci., 2013.

[23] M. Van Tulder, T. Touray, A. Furlan, and et al, "Muscle relaxants for non-specific low-back pain ( Review ) Muscle relaxants for nonspecific low-back pain," The Cochrane Collaberation, 2008.

[24] D. D. Chiras, "Principles of sustainable development: A new paradigm for the twenty first century," J. Environ. Sci. Heal. Part C, 1995.

[25] M. I. Gunawan and S. A. Barringer, "Green color degradation of blanched broccoli (Brassica Oleracea) due to acid and microbial growth," J. Food Process. Preserv., 2000.

[26] P. J. Wilkie, G. Hatzimihalis, P. Koutoufides, and M. A. Connor, "The contribution of domestic sources to levels of key organic and inorganic pollutants in sewage: The case of Melbourne, Australia," in Water Science and Technology, 1996.

[27] M. N. Ingale and V. V. Mahajani, "Recovery of carboxylic acids, C2C6, from an aqueous waste stream using tributylphosphate(TBP): Effect of presence of inorganic acids and their sodium salts," Sep. Technol., 1996.

[28] A. J. McCullough and M. A. Schuler, "AU-rich intronic elements affect pre-mRNA 5' splice site selection in Drosophila melanogaster.," Mol. Cell. Biol., 1993.

[29] L. A. Boos, A. J. Szalai, and S. R. Barnum, "Murine complement C4 is not required for experimental autoimmune encephalomyelitis," Glia, 2005.

[30] M. C. Díaz-Maroto, N. Castillo, L. Castro-Vázquez, C. de Torres, and M. S. Pérez-Coello, "Authenticity Evaluation of Different Mints based on their Volatile Composition and Olfactory Profile," $J$ Essent. Oil-Bearing Plants, 2008.

[31] D. S. Page, P. D. Boehm, G. S. Douglas, A. E. Bence, W. A. Burns, and P. J. Mankiewicz, "The natural petroleum hydrocarbon background in subtidal sediments of Prince William Sound, Alaska, USA," Environ. Toxicol. Chem., 1996.

[32] M. Rhodes, Introduction to Particle Technology: Second Edition. 2008.

[33] G. F. Mu'min, P. Prawisudha, I. N. Zaini, M. Aziz, and A. D. Pasek, "Municipal solid waste processing and separation employing wet torrefaction for alternative fuel production and aluminum reclamation," Waste Manag., 2017.

[34] B. Pauwels and W. Verstraete, "The treatment of hospital wastewater: An appraisal," J. Water Health, 2006.

[35] A. R. Mesdaghinia, K. Naddafi, R. Nabizadeh, R. Saeedi, and M. Zamanzadeh, "Wastewater characteristics and appropriate method for wastewater management in the hospitals," Iran. J. Public Health, 2009 . 